Article

\title{
In Situ Investigations on the Facile Synthesis and Catalytic Performance of $\mathrm{CeO}_{2}-\mathrm{Pt} / \mathrm{Al}_{2} \mathrm{O}_{3}$ Catalyst
}

\author{
Chengxiong Wang ${ }^{1,2,3}$, Dezhi Ren ${ }^{2,3}$, Junchen Du ${ }^{2,3}$, Qinggao Qin ${ }^{3}$, Aimin Zhang ${ }^{1}$, Li Chen ${ }^{1,2}$, \\ Hao Cui ${ }^{1}$, Jialin Chen ${ }^{1,2}$ and Yunkun Zhao ${ }^{1,2,3, *(D)}$ \\ 1 Sino-Precious Metals Holding Co., Ltd., 988 Keji Road, Hi-tech Development Zone, Kunming 650106, China; \\ wangchengxiong@ipm.com.cn (C.W.); aimin.zhang@ipm.com.cn (A.Z.); chenli@ipm.com.cn (L.C.); \\ cuihao@ipm.com.cn (H.C.); cjl@ipm.com.cn (J.C.) \\ 2 State Key Laboratory of Advanced Technologies for Comprehensive Utilization of Platinum Metals, \\ Kunming Institute of Precious Metals, Kunming 650106, China; SPMCrendezhi@163.com (D.R.); \\ junchen.du@spmcatalyst.com (J.D.) \\ 3 State-Local Joint Engineering Laboratory of Precious Metal Catalytic Technology and Application, \\ Kunming Sino-Platinum Metals Catalysts Co. Ltd., Kunming 650106, China; qinggao.qin@spmcatalyst.com \\ * Correspondence: yk.zhao@spmcatalyst.com; Tel.: +86-135-0871-6996
}

Received: 24 December 2019; Accepted: 18 January 2020; Published: 21 January 2020

check for updates

\begin{abstract}
Ceria-modified $\mathrm{Pt} / \mathrm{Al}_{2} \mathrm{O}_{3}$ catalyst has been commonly prepared by the impregnation of platinum on ceria-modified alumina and widely applied in the chemical industry and automotive industry. The in situ diffuse reflectance infrared Fourier transformed spectroscopy (DRIFTS), and thermogravimetric (TG) analysis techniques were employed to investigate the typical mechanisms of the bis(ethanolammonium)hexahydroxyplatinate(IV) and cerium nitrate decomposition catalyzed by $\mathrm{Pt}^{\delta+}$ species for the facile synthesis of $\mathrm{CeO}_{2}-\mathrm{Pt} / \mathrm{Al}_{2} \mathrm{O}_{3}$ catalyst. It was found that $\mathrm{Pt}^{4+}$-catalyzed decomposition of cerium nitrate leads to the higher dispersity of ceria and forming more active oxygen species, on the basis of X-ray diffraction (XRD) and $\mathrm{H}_{2}$ temperature-programmed reduction $\left(\mathrm{H}_{2}-\mathrm{TPR}\right)$ results. The in situ activity measurements were also performed to investigate the reaction mechanisms and the specific activities for the catalytic $\mathrm{CO}, \mathrm{NO}, \mathrm{C}_{3} \mathrm{H}_{6}$ and $\mathrm{C}_{3} \mathrm{H}_{8}$ co-oxidation. The results indicate that undesirable $\mathrm{N}_{2} \mathrm{O}$ by-product is formed by the selective catalytic reduction (SCR) of $\mathrm{NO}$ by $\mathrm{C}_{3} \mathrm{H}_{6}$ below $350{ }^{\circ} \mathrm{C}$. The cerium addition effectively improves the activity of catalytic oxidation, but exhibits an increased $\mathrm{N}_{2} \mathrm{O}$ yield, due to the increased reducibility.
\end{abstract}

Keywords: platinum; ceria; in situ characterization; catalytic oxidation

\section{Introduction}

Platinum-based catalysts have been widely used in the chemical industry for the catalytic dehydrogenation of light alkanes, such as ethane and propane [1,2], as well as the automotive industry to catalytically oxidize harmful pollutants, including CO, NO, and hydrocarbons [3-6]. Ceria has been used in automotive catalysts, due to its oxygen storage capacity and the ability to stabilize active metals [7-9]. The recognized ability of ceria to undergo rapid reduction/oxidation cycles $\left(4 \mathrm{CeO}_{2} \rightleftharpoons\right.$ $2 \mathrm{Ce}_{2} \mathrm{O}_{3}+\mathrm{O}_{2}$ ) plays a significant role in providing oxygen mobility and oxygen storage/release [8]. In our previous investigations, it was reported that the synergy between ceria additive and active $\mathrm{Pt}$ species has a positive impact on the stability of coordinately unsaturated $\mathrm{Pt}^{2+}$ and $\mathrm{Pt}^{4+}$ species, thereby drives $\mathrm{C}-\mathrm{C}$ and $\mathrm{C}-\mathrm{H}$ bonds activation and promotes low-temperature oxidation of propane [10]. Ceria can also stabilize atomically dispersed ionic platinum $\left(\mathrm{Pt}^{2+}\right.$ species) to accelerate CO oxidation at low temperature [11]. The shape-dependent ability to anchor single $\mathrm{Pt}^{2+}$ species increases in the order: Ceria cubes $<$ ceria nanorods $<$ polyhedral ceria [9]. Bruix [12] et al. suggested that the unsaturated $\mathrm{Pt}^{2+}$ species is effectively stabilized by bonding to $\mathrm{O}^{2-}$ sites in square pockets of $\mathrm{CeO}_{2}$ surfaces. 
The ceria addition into Pt-based diesel oxidation catalyst (DOC) showed the positive impact on the improvement of platinum dispersion, and generation of more active oxygen species and oxygen vacancies over the catalyst, which strengthens the interactions between $\mathrm{NO}$ molecules and the catalyst surfaces to promote $\mathrm{NO}$ oxidation into $\mathrm{NO}_{2}$ and form nitrate species [13]. The introduction of cerium into $\mathrm{Pt} / \mathrm{Al}_{2} \mathrm{O}_{3}$ catalyst leads to enhancing the dispersity of active $\mathrm{Pt}$ nanoparticles and reducibility of catalyst, which was reported by Ma et al. [14]. They also found that the Ce-containing $\mathrm{Pt} / \mathrm{Al}_{2} \mathrm{O}_{3}$ catalyst exhibits more active for propane dehydrogenation and higher coking-resistant ability than Ce-free $\mathrm{Pt} / \mathrm{Al}_{2} \mathrm{O}_{3}$ catalyst. As a doping element, cerium addition to alumina increases the thermal stability of alumina and improves the ability to remove carbon species during partial oxidation of methane [15]. Improved effectiveness of the carbon cleaning promotes the reactivity of partial oxidation of methane. Promotion of $\mathrm{Pt} / \mathrm{Al}_{2} \mathrm{O}_{3}$ by cerium for $\mathrm{CO}$ oxidation was also found by Son and his co-workers $[16,17]$, due to the enhanced oxygen supply to the Pt sites.

Some methods for cerium addition into $\mathrm{Al}_{2} \mathrm{O}_{3}$ supported catalyst have been reported, for instance, incipient wetness impregnation [10], controlled surface reaction (CSR) technique [18], and atomic layer deposition (ALD) technique [19]. The latter two methods can effectively improve the dispersity of ceria, but the use of expensive organometallics, such as $\mathrm{Ce}(\mathrm{acac})_{3}$ (cerium acetylacetonate) and $\mathrm{Ce}(\mathrm{TMHD})_{4}$ (tetrakis(2,2,6,6-tetramethyl-3,5-heptanedionato)cerium) is required to prepare the $\mathrm{CeO}_{2-x} / \mathrm{Pt} / \mathrm{Al}_{2} \mathrm{O}_{3}$ catalyst. By contrast, the incipient wetness impregnation method was considered as the most practical method, resulting from requiring the use of low-cost inorganic precursors, such as $\mathrm{Ce}\left(\mathrm{NO}_{3}\right)_{3}$ (cerium nitrate) and $\left(\mathrm{NH}_{4}\right)_{2}\left[\mathrm{Ce}\left(\mathrm{NO}_{3}\right)_{6}\right]$ (diammonium hexanitrate cerate) $[10,20]$. The cerium addition by incipient wetness impregnation using $\mathrm{Ce}\left(\mathrm{NO}_{3}\right)_{3}$ has been successfully employed to prepare the highly-efficient automotive catalysts [13]. However, the structure evolution of precursors is still unknown during the process for preparing the cerium-modified $\mathrm{Pt} / \mathrm{Al}_{2} \mathrm{O}_{3}$ catalyst.

It is worth mentioning that the choice of platinum precursors is also very important for the preparation of $\mathrm{Pt}$ catalysts by the incipient wetness impregnation method [21]. The typical Pt-precursors, such as $\mathrm{H}_{2} \mathrm{PtCl}_{6}$ (hexachloroplatinic(IV) acid), $\mathrm{Pt}\left(\mathrm{NO}_{3}\right)_{2}$ (platinum(II) nitrate) and $\mathrm{Pt}\left(\mathrm{NH}_{3}\right)_{4}\left(\mathrm{NO}_{3}\right)_{2}$ (tetraammineplatinum(II) nitrate), were used to prepare those Pt-supported catalysts [22,23]. However, the use of $\mathrm{H}_{2} \mathrm{PtCl}_{6}$ as a precursor will lead to the introduction of chlorine, although the tetravalent state of platinum readily interacts with non-stoichiometric oxides. By contrast, using a new $\left[\mathrm{HOCH}_{2} \mathrm{CH}_{2} \mathrm{NH}_{3}\right]_{2} \mathrm{Pt}(\mathrm{OH})_{6}$ (bis(ethanolammonium)hexahydroxyplatinate(IV)) as the Pt-precursor can refrain from chlorine incorporation and its hydroxyls can bond to the surface of oxide support with hydrogen bonds to strengthen the interactions between platinum precursors and support. In the work, therefore, some in situ characterization techniques were used to investigate the facile synthesis of $\mathrm{CeO}_{2}-\mathrm{Pt} / \mathrm{Al}_{2} \mathrm{O}_{3}$ catalyst by impregnation method using $\mathrm{Ce}\left(\mathrm{NO}_{3}\right)_{3}$ and $\left[\mathrm{HOCH}_{2} \mathrm{CH}_{2} \mathrm{NH}_{3}\right]_{2} \mathrm{Pt}(\mathrm{OH})_{6}$ as the precursors and test the catalytic performance for $\mathrm{CO}, \mathrm{NO}, \mathrm{C}_{3} \mathrm{H}_{6}$ and $\mathrm{C}_{3} \mathrm{H}_{8}$ co-oxidation.

\section{Results and Discussion}

\subsection{Thermogravimetric Results}

The thermogravimetric (TG) analysis of the different samples was carried out, and the results were displayed in Figure 1. The pure $\mathrm{Al}_{2} \mathrm{O}_{3}$ sample shows a slight, but consecutive weight loss up to $550{ }^{\circ} \mathrm{C}$, which can be ascribed to the dehydration of sample and the decomposition of chemically adsorbed hydroxyl species [24]. By contrast, the introduction of Pt-precursor induces the additional weight loss that is reasonably related to the decomposition of chemical fragments from $\left[\mathrm{HOCH}_{2} \mathrm{CH}_{2} \mathrm{NH}_{3}\right]_{2} \mathrm{Pt}(\mathrm{OH})_{6}$. As for the Ce-containing samples, the weight loss is largely higher compared to those of Ce-free samples, which can be assigned to the transformation and thermal decomposition of nitrate precursors. 


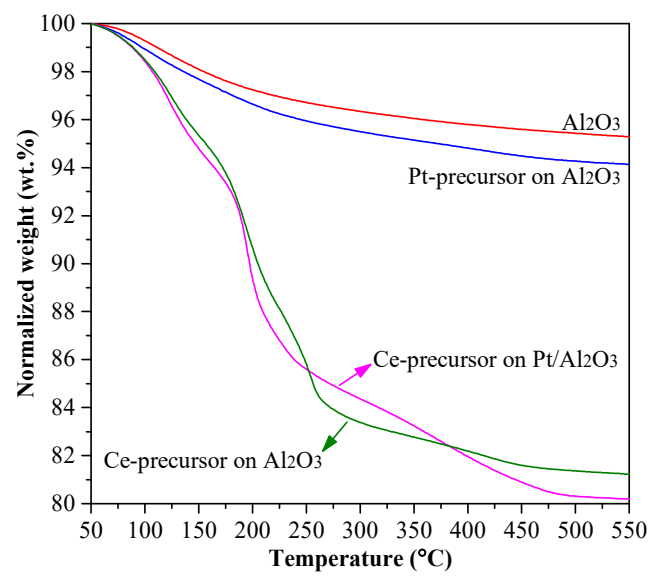

Figure 1. Thermogravimetric (TG) curves of the different samples at a heating rate of $10^{\circ} \mathrm{C} / \mathrm{min}$ in $\mathrm{N}_{2}$ steam.

\subsection{Decomposition of Pt-Precursor}

The TG curve for the decomposition of Pt-precursor on $\mathrm{Al}_{2} \mathrm{O}_{3}$ powder was achieved through subtracting TG data of pure $\mathrm{Al}_{2} \mathrm{O}_{3}$ (Figure 1) from the data of the pristine Pt/alumina powder without calcination. The obtained TG curve and the corresponding derivative thermogravimetric (DTG) curve were displayed in Figure 2a. The TG curve can be divided into three weight loss steps according to the DTG curve. Step 1 with weight loss of $0.41 \mathrm{mg}$ per $100 \mathrm{mg}$ sample, where a temperature ranges from $50{ }^{\circ} \mathrm{C}$ to $135^{\circ} \mathrm{C}$, represents the weight loss by the removal of physically adsorbed water [25]. Step 2 removes $\mathrm{H}_{2} \mathrm{O}$ molecules from $\mathrm{Pt}(\mathrm{OH})_{6}{ }^{2-}$ species [26]. In the TG experiment, the theoretical weight loss for the complete decomposition of $\mathrm{Pt}(\mathrm{OH})_{6}{ }^{2-}$ species is $0.27 \mathrm{mg}$. However, the actual weight loss in this step reaches to $0.51 \mathrm{mg}$, indicating that partial $\mathrm{HOCH}_{2} \mathrm{CH}_{2} \mathrm{NH}_{3}{ }^{+}$species starts to be transformed in the step. Increasing the temperature to $482{ }^{\circ} \mathrm{C}$, the total weight loss reaches $1.16 \mathrm{mg}$. However, no significant change in weight loss was observed with the further temperature increments. It is assumed that Pt-precursor was completely decomposed into $\mathrm{PtO}_{2}$ and gas; the total weight loss would be $1.38 \mathrm{mg}$. The gapped results between actual and theoretical weight loss can be contributed to the formation of coke during decomposition of Pt-precursor, as well as some errors during the data processing.
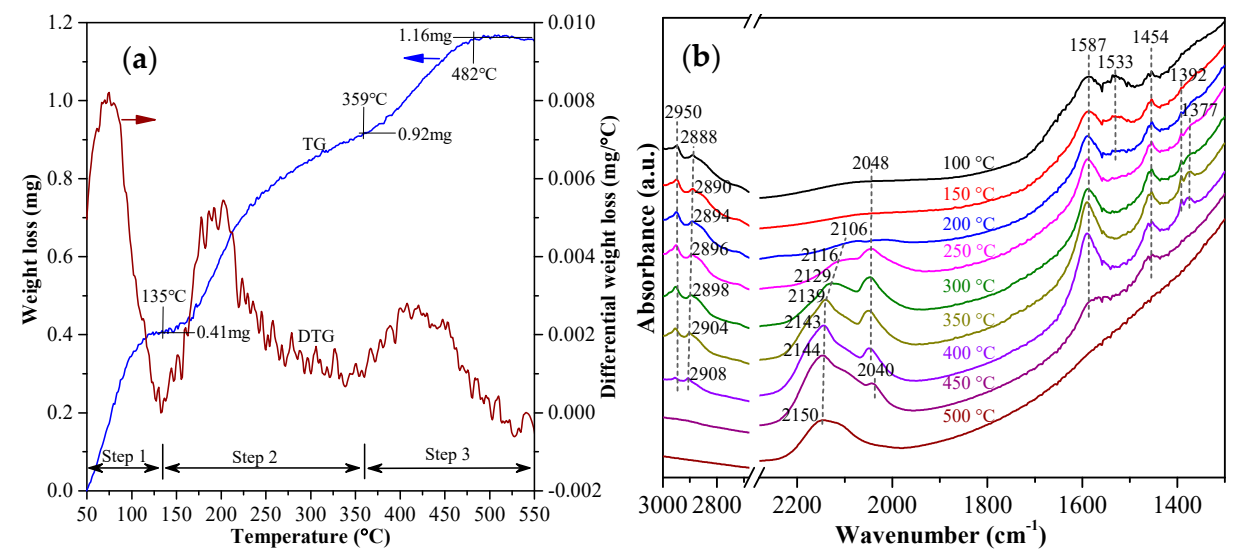

Figure 2. TG and derivative thermogravimetric (DTG) curves (a) and diffuse reflectance infrared Fourier transformed spectroscopy (DRIFTS) spectra (b) collected during thermal decomposition of Pt-precursor on $\mathrm{Al}_{2} \mathrm{O}_{3}$ powder at a heating rate of $10^{\circ} \mathrm{C} / \mathrm{min}$ in $\mathrm{N}_{2}$ steam.

Further evidence for the transformation of $\mathrm{Pt}$ complexes during the programmed temperature procedure in $\mathrm{N}_{2}$ steam was provided by diffuse reflectance infrared Fourier transformed spectroscopy 
(DRIFTS), as displayed in Figure $2 \mathrm{~b}$. The band centered at $1454 \mathrm{~cm}^{-1}$ can be assigned to deformation vibration of the methylene group $\delta\left(\mathrm{CH}_{2}\right)$ from $\mathrm{HOCH}_{2} \mathrm{CH}_{2} \mathrm{NH}_{3}{ }^{+}$species, and the corresponding symmetric and asymmetric vibrations were respectively observed at $2888 \mathrm{~cm}^{-1}, v_{\mathrm{s}}\left(\mathrm{CH}_{2}\right)$, and $2950 \mathrm{~cm}^{-1}$, $v_{\text {as }}\left(\mathrm{CH}_{2}\right)$ [27]. The shoulder at $1533 \mathrm{~cm}^{-1}$ should be related with $\mathrm{O}-\mathrm{H}$ bending mode in water [28]. The local peak centered at $1587 \mathrm{~cm}^{-1}$ corresponds to the bending mode of the $\mathrm{Pt}-\mathrm{NH}_{3}$ species [29]. Increasing temperature from $100{ }^{\circ} \mathrm{C}$ to $20{ }^{\circ} \mathrm{C}$ only led to a significant decrease in the intensity of the bending vibration hydroxyl group $\delta(\mathrm{OH})$ in water, which illustrates water loss in the catalyst sample. Carbonyl (bands at $2070 \sim 2040 \mathrm{~cm}^{-1}$, linear bonded Pt-CO species) and isocyanate surface complexes (bands at $2150 \sim 2100 \mathrm{~cm}^{-1}$, Pt-NCO species) [30,31] first clearly appeared at $250{ }^{\circ} \mathrm{C}$. With further increments in temperature, the Pt-NCO vibrational bands showed an increase in intensity and a shift towards higher wavenumbers, reaching $2150 \mathrm{~cm}^{-1}$ at $500{ }^{\circ} \mathrm{C}$, while the band at $2048 \mathrm{~cm}^{-1}$ assigned to Pt-CO species shifted toward $2040 \mathrm{~cm}^{-1}$ at $450{ }^{\circ} \mathrm{C}$ and disappeared at $500{ }^{\circ} \mathrm{C}$. The blue-shift of $v_{\mathrm{s}}(\mathrm{NCO})$ reflects increasing $\mathrm{NCO}$ coverage, due to the further transformation of $\mathrm{HOCH}_{2} \mathrm{CH}_{2} \mathrm{NH}_{3}{ }^{+}$ species. In addition, three were also the formation of some surface oxy-carbon species, including enolates $\left(1392 \mathrm{~cm}^{-1}, v_{\mathrm{s}}\left(\mathrm{CH}_{2}=\mathrm{CH}-\mathrm{O}\right)\right)$ [32], and formates $\left(1377 \mathrm{~cm}^{-1}, v_{\mathrm{s}}(\mathrm{COO})\right)$ [33] in the temperature regions of $250 \sim 400^{\circ} \mathrm{C}$. According to TG and in situ DRIFTS results, the thermal decomposition process of Pt-precursor can be summarized as the following reaction (I):

$\left[\mathrm{HOCH}_{2} \mathrm{CH}_{2} \mathrm{NH}_{3}\right]_{2} \mathrm{Pt}(\mathrm{OH})_{6} \rightarrow \mathrm{Pt}-\mathrm{CO}+\mathrm{Pt}-\mathrm{NCO}+$ oxy-carbon $\rightarrow \mathrm{Pt}-\mathrm{NCO}+\mathrm{Pt}$ sites.

\subsection{Decomposition of Ce-Precursor}

In Figure $3 \mathrm{a}, \mathrm{c}$, the weight loss at the temperature range of $50 \sim 138^{\circ} \mathrm{C}$ is assigned to the removal of physically adsorbed water, while the other weight loss at higher temperature corresponds to removing chemically bound water and $\mathrm{NO}_{3}{ }^{-}$species [24]. As showed in Figure 3a, a significant weight loss of $10.54 \mathrm{mg}$ was observed in the temperature regions of $138 \sim 296{ }^{\circ} \mathrm{C}$, primarily, due to the transformation and decomposition of $\mathrm{NO}_{3}{ }^{-}$species. The TG curve showed in Figure $3 c$ exhibited a total weight loss of $11.06 \mathrm{mg}$ up to $248{ }^{\circ} \mathrm{C}$ and a maximum weight loss rate of $0.243 \mathrm{mg} /{ }^{\circ} \mathrm{C}$ at $195{ }^{\circ} \mathrm{C}$. The decomposition temperature of $\mathrm{Ce}$-precursor on $\mathrm{Pt} /$ alumina was lower, and the maximum weight loss rate was higher compared to that of Ce-precursor on $\mathrm{Al}_{2} \mathrm{O}_{3}$, which indicates the occurrence of Pt-catalyzed decomposition of cerium nitrate. The total weight losses in Figure 3a,c were $14.03 \mathrm{mg}$ and $15.11 \mathrm{mg}$ per $100 \mathrm{mg}$ sample, respectively, showing the weight gap of $1.08 \mathrm{mg}$ that is closely related to the decomposition of Pt-precursor.

From Figure $3 \mathrm{~b}$, it can be seen that Ce-precursor on $\mathrm{Al}_{2} \mathrm{O}_{3}$ started to transform bridging nitrates $\left(1650 \sim 1600 \mathrm{~cm}^{-1},(\mathrm{Ce}-\mathrm{O})_{2}=\mathrm{NO}\right)$ and monodentate nitrates $\left(1530 \sim 1480 \mathrm{~cm}^{-1}, \mathrm{Ce}-\mathrm{ONO}_{2}\right)$ into chelating bidentate nitrates (bands at $1585 \sim 1530 \mathrm{~cm}^{-1}, \mathrm{Ce}-\mathrm{O}_{2} \mathrm{NO}$ ) [34-36] above $150{ }^{\circ} \mathrm{C}$, and the vibrational bands of nitrates disappeared with the temperature increment up to $450{ }^{\circ} \mathrm{C}$. This indicates that the following reactions for the thermal decomposition of cerium(III) nitrate are accomplished, as showed in the reaction (II) reported by Wendlandt et al. [37]. Compared with the DRIFTS spectra for the thermal decomposition process of Ce-precursor on $\mathrm{Al}_{2} \mathrm{O}_{3}$, the ones of Ce-precursor on Pt/alumina (Figure 3d) exhibited a weaker intensity in stretching vibrations of bridging nitrates at lower wavenumber (centered at $1616 \mathrm{~cm}^{-1}$ ) and bands in the $2200 \sim 2100 \mathrm{~cm}^{-1}$ region assigned to $\mathrm{N}_{2} \mathrm{O}, \mathrm{N}_{2}, \mathrm{NO}_{2}{ }^{+}$, and $\mathrm{NO}^{+}$[36]. In addition, the DRIFTS spectrum at $400{ }^{\circ} \mathrm{C}$ in Figure $3 \mathrm{~d}$ exhibits a significantly weaker intensity in $\mathrm{Ce}-\mathrm{O}_{2} \mathrm{NO}$ mode at $1552 \mathrm{~cm}^{-1}$ than the decomposition of Ce-precursor on $\mathrm{Al}_{2} \mathrm{O}_{3}$. The results can be ascribed to Pt-catalyzed decomposition of nitrates that promotes the removal of $\mathrm{NO}_{3}{ }^{-}$species and the formation of $\mathrm{CeO}_{2-x}$. These promotional effects would be conducive to the enhancement of $\mathrm{Pt}-\mathrm{CeO}_{2-x}$ interactions, due to the in situ reduction of $\mathrm{Pt}^{\delta+}$ species by $\mathrm{Ce}^{3+}$ ions in an inert atmosphere,

$$
\mathrm{Ce}\left(\mathrm{NO}_{3}\right)_{3} \cdot x \mathrm{H}_{2} \mathrm{O}(\mathrm{s}) \rightarrow \mathrm{Ce}\left(\mathrm{NO}_{3}\right)_{3}(\mathrm{~s}) \rightarrow \mathrm{CeONO}_{3}(\mathrm{~s}) \rightarrow \mathrm{CeO}_{2-x}(\mathrm{~s}) .
$$



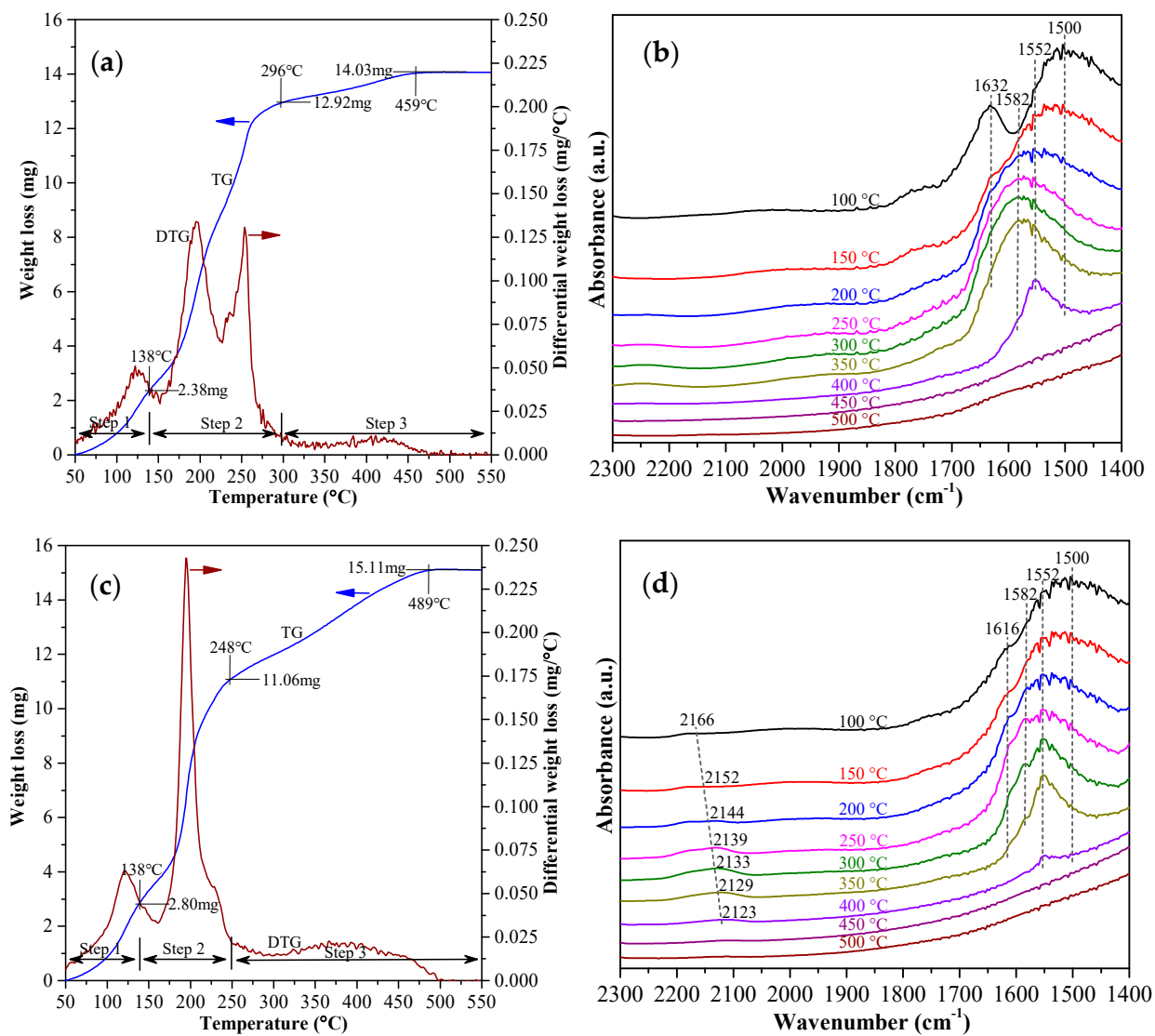

Figure 3. TG and DTG curves (a,c) and DRIFTS spectra $(\mathbf{b}, \mathbf{d})$ collected during thermal decomposition of Ce-precursor on $\mathrm{Al}_{2} \mathrm{O}_{3}(\mathbf{a}-\mathbf{b})$ and $\mathrm{Pt}_{2} / \mathrm{Al}_{2} \mathrm{O}_{3}(\mathbf{c}-\mathbf{d})$ powders at a heating rate of $10^{\circ} \mathrm{C} / \mathrm{min}$ in $\mathrm{N}_{2}$ steam.

\subsection{Catalytic Performance}

The activities of catalytic $\mathrm{CO}, \mathrm{NO}, \mathrm{C}_{3} \mathrm{H}_{6}$ and $\mathrm{C}_{3} \mathrm{H}_{8}$ co-oxidation over the Pt-supported catalysts were performed on a continuous flow fixed-bed micro-reactor. The results of activity measurements were showed in Figure 4, and the corresponding characteristic temperatures were summarized in Table 1. The activity of different reactions over the $\mathrm{Pt} / \mathrm{Al}_{2} \mathrm{O}_{3}$ catalyst was easily distinguished, decreasing in the order: $\mathrm{CO}$ oxidation $>\mathrm{C}_{3} \mathrm{H}_{6}$ oxidation $>\mathrm{NO}$ oxidation $>\mathrm{C}_{3} \mathrm{H}_{8}$ oxidation according to the light-off curves (showed in Figure 4a). The catalytic oxidation of hydrocarbons required the higher reaction temperature than $\mathrm{CO}$ oxidation, in particular for $\mathrm{C}_{3} \mathrm{H}_{8}$ oxidation, owing to the higher reactivity of $\mathrm{CO}$ oxidation on $\mathrm{Pt}$ active sites compared to that of hydrocarbons [3]. The activity of $\mathrm{C}_{3} \mathrm{H}_{6}$ oxidation is higher than $\mathrm{NO}$ oxidation, due to the $\mathrm{NO}$ oxidation inhibition by $\mathrm{C}_{3} \mathrm{H}_{6}$ over the $\mathrm{Pt} / \mathrm{Al}_{2} \mathrm{O}_{3}$ catalyst [38]. 


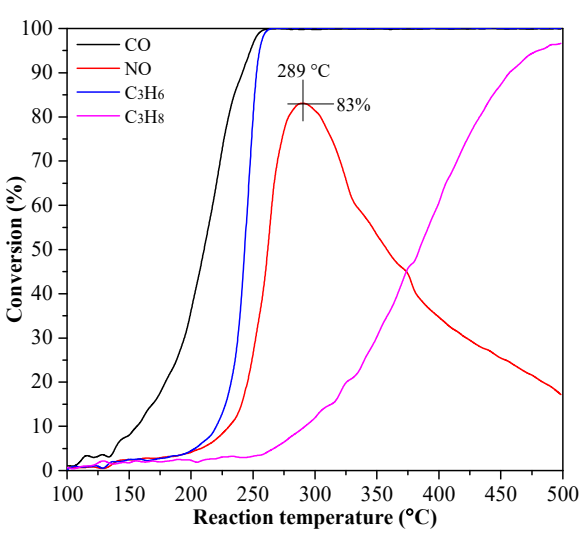

(a)

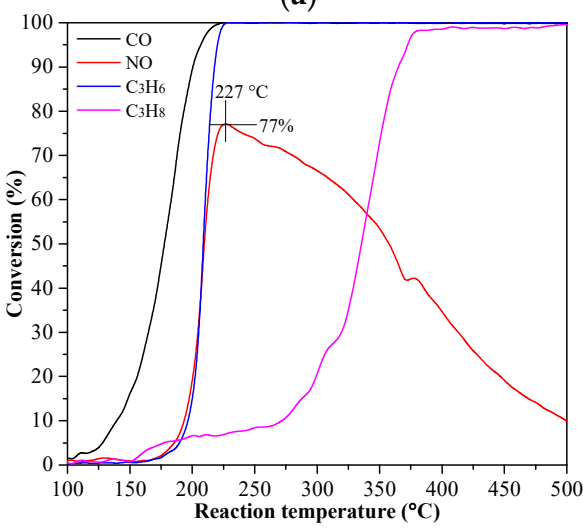

(c)

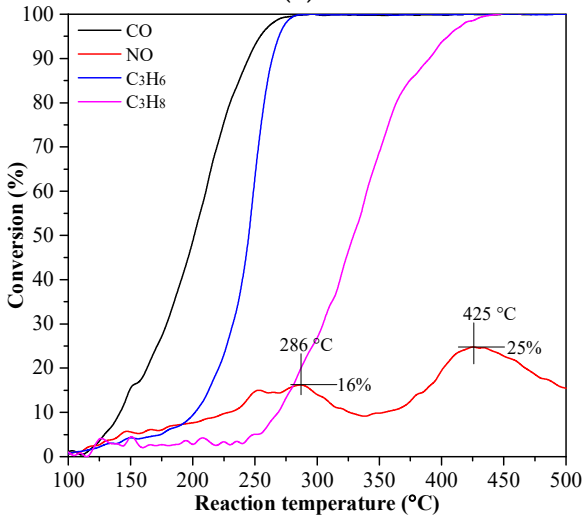

(e)

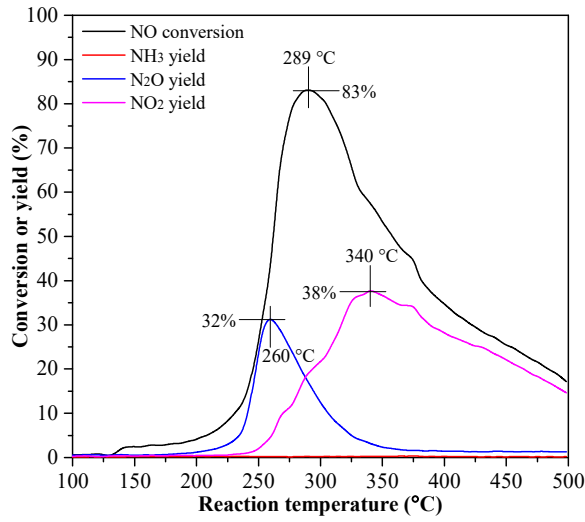

(b)

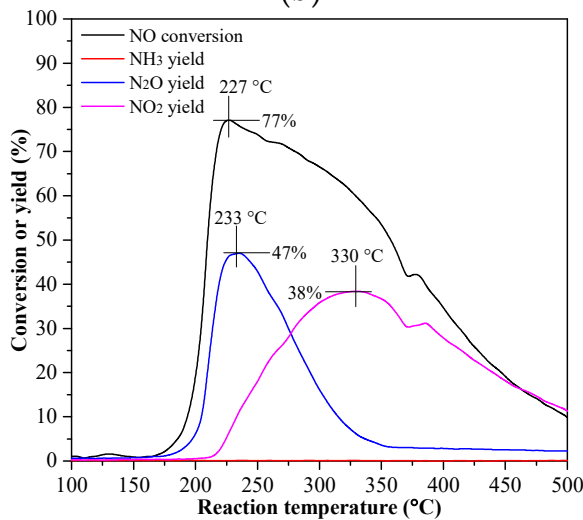

(d)

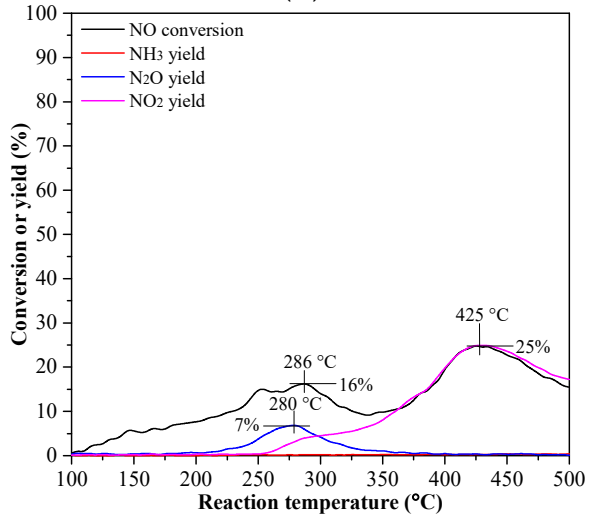

(f)

Figure 4. Conversion $(\mathbf{a}, \mathbf{c})$ and yield $(\mathbf{b}, \mathbf{d})$ curves during catalytic oxidation reactions over the $\mathrm{Pt} / \mathrm{Al}_{2} \mathrm{O}_{3}(\mathbf{a}, \mathbf{b}), \mathrm{CeO}_{2}-\mathrm{Pt} / \mathrm{Al}_{2} \mathrm{O}_{3}(\mathbf{c}, \mathbf{d})$ and reference $(\mathbf{e}, \mathbf{f})$ catalysts.

In the case of $\mathrm{NO}$ conversion, no $\mathrm{NH}_{3}$ product was detected, but significant $\mathrm{N}_{2} \mathrm{O}$ (below $350{ }^{\circ} \mathrm{C}$ ) and $\mathrm{NO}_{2}$ (above $250^{\circ} \mathrm{C}$ ) products were formed. $\mathrm{NO}$ molecule started to be consumed when $\mathrm{CO}$ oxidation reached near to complete conversion, showing the maximum NO conversion rate of $83 \%$ at $289{ }^{\circ} \mathrm{C}$, maximum $\mathrm{N}_{2} \mathrm{O}$ yield of $32 \%$ at $260{ }^{\circ} \mathrm{C}$ and maximum $\mathrm{NO}_{2}$ yield of $38 \%$ at $340{ }^{\circ} \mathrm{C}$. The results indicate that $\mathrm{NO}$ was transferred into undesirable $\mathrm{N}_{2} \mathrm{O}$ via the selective catalytic reduction (SCR) of $\mathrm{NO}$ by $\mathrm{C}_{3} \mathrm{H}_{6}$ at low temperature and oxidized into desirable $\mathrm{NO}_{2}$ in the higher temperature regions. The related reactions include:

$$
\begin{gathered}
2 \mathrm{NO}+\mathrm{C}_{3} \mathrm{H}_{6}+4 \mathrm{O}_{2} \rightarrow \mathrm{N}_{2} \mathrm{O}+3 \mathrm{CO}_{2}+3 \mathrm{H}_{2} \mathrm{O}, \\
2 \mathrm{NO}+\mathrm{O}_{2} \rightarrow 2 \mathrm{NO}_{2} .
\end{gathered}
$$


Table 1. The characteristic temperatures for catalytic oxidation of $\mathrm{CO}, \mathrm{NO}, \mathrm{C}_{3} \mathrm{H}_{6}$ and $\mathrm{C}_{3} \mathrm{H}_{8}$ over the $\mathrm{Pt} / \mathrm{Al}_{2} \mathrm{O}_{3}$ and $\mathrm{CeO}_{2}-\mathrm{Pt} / \mathrm{Al}_{2} \mathrm{O}_{3}$ catalysts.

\begin{tabular}{|c|c|c|c|c|c|c|c|c|}
\hline \multirow{2}{*}{ Samples } & \multicolumn{2}{|c|}{$\mathrm{CO}$} & \multicolumn{2}{|c|}{ NO } & \multicolumn{2}{|c|}{$\mathrm{C}_{3} \mathrm{H}_{6}$} & \multicolumn{2}{|c|}{$\mathrm{C}_{3} \mathrm{H}_{8}$} \\
\hline & $T_{50}{ }^{a}$ & $T_{90}^{b}$ & $T_{50}$ & $T_{90}$ & $T_{50}$ & $T_{90}$ & $T_{50}$ & $T_{90}$ \\
\hline $\mathrm{Pt} / \mathrm{Al}_{2} \mathrm{O}_{3}$ & 210.6 & 241.3 & 262.2 & nd $^{c}$ & 243.3 & 252.0 & 384.0 & 456.8 \\
\hline $\mathrm{CeO}_{2}-\mathrm{Pt} / \mathrm{Al}_{2} \mathrm{O}_{3}$ & 177.7 & 200.1 & 209.5 & nd & 208.8 & 217.6 & 335.5 & 364.8 \\
\hline $\begin{array}{c}\text { Reference } \\
\text { catalyst }\end{array}$ & 201.2 & 244.7 & nd & nd & 245.2 & 264.0 & 329.1 & 390.4 \\
\hline$\Delta_{1}^{\mathrm{d}}$ & 32.9 & 41.2 & 52.7 & nd & 34.5 & 34.4 & 48.5 & 92.0 \\
\hline$\Delta_{2}{ }^{\mathrm{e}}$ & 23.5 & 44.6 & nd & nd & 36.4 & 46.4 & -6.4 & 25.6 \\
\hline
\end{tabular}

\footnotetext{
${ }^{\text {a }} T_{50}$ is the specific temperature reached the conversion of $50 \%$, so-called "light-off temperature". ${ }^{\mathrm{b}} T_{90}$ is the specific temperature reached the conversion of $90 \% .{ }^{c}$ nd $=$ no data. ${ }^{\mathrm{d}} \Delta_{1}$ represents the characteristic temperature gap between $\mathrm{Pt} / \mathrm{Al}_{2} \mathrm{O}_{3}$ and $\mathrm{CeO}_{2}-\mathrm{Pt} / \mathrm{Al}_{2} \mathrm{O}_{3}$ catalyst. ${ }^{\mathrm{e}} \Delta_{2}$ represents the characteristic temperature gap between the reference catalyst and $\mathrm{CeO}_{2}-\mathrm{Pt} / \mathrm{Al}_{2} \mathrm{O}_{3}$ catalyst.
}

By comparison with $\mathrm{Pt} / \mathrm{Al}_{2} \mathrm{O}_{3}$, the $\mathrm{NO}$ conversion curve almost entirely overlapped with the one of $\mathrm{C}_{3} \mathrm{H}_{6}$ with a higher $\mathrm{N}_{2} \mathrm{O}$ yield over the $\mathrm{CeO}_{2}-\mathrm{Pt}_{2} / \mathrm{Al}_{2} \mathrm{O}_{3}$ catalyst up to $210{ }^{\circ} \mathrm{C}$, illustrating that the low-temperature $\mathrm{C}_{3} \mathrm{H}_{6}$-SCR activity was improved, due to the increased reducibility by the addition of ceria [39]. In addition, the $\mathrm{CeO}_{2}-\mathrm{Pt} / \mathrm{Al}_{2} \mathrm{O}_{3}$ catalyst exhibited a lower temperature to achieve the maximum $\mathrm{NO}$ conversion rate, $\mathrm{N}_{2} \mathrm{O}$ and $\mathrm{NO}_{2}$ yield. From Table 1, it can also be observed that the ceria addition led to a significant $T_{50}$ decrease of $32.9^{\circ} \mathrm{C}, 52.7^{\circ} \mathrm{C}, 34.5^{\circ} \mathrm{C}, 48.5^{\circ} \mathrm{C}$, respectively, for the $\mathrm{CO}, \mathrm{NO}, \mathrm{C}_{3} \mathrm{H}_{6}$ and $\mathrm{C}_{3} \mathrm{H}_{8}$ conversion. The $\mathrm{T}_{90}$ gaps between $\mathrm{Pt} / \mathrm{Al}_{2} \mathrm{O}_{3}$ and $\mathrm{CeO}_{2}-\mathrm{Pt} / \mathrm{Al}_{2} \mathrm{O}_{3}$ catalyst for $\mathrm{CO}$ and $\mathrm{C}_{3} \mathrm{H}_{8}$ conversions are higher than the corresponding $T_{50}$ gaps, reaching $41.2{ }^{\circ} \mathrm{C}$ and $92.0^{\circ} \mathrm{C}$, respectively. These results indicate that the ceria addition significantly promotes low-temperature catalytic oxidation of $\mathrm{CO}, \mathrm{NO}, \mathrm{C}_{3} \mathrm{H}_{6}$ and $\mathrm{C}_{3} \mathrm{H}_{8}$, which agree well with the literature $[10,13,16,20]$. In addition, the $\mathrm{CeO}_{2}-\mathrm{Pt} / \mathrm{Al}_{2} \mathrm{O}_{3}$ catalyst showed the lower characteristic temperatures for $\mathrm{CO}, \mathrm{NO}$ and $\mathrm{C}_{3} \mathrm{H}_{6}$ conversion than that of the reference catalyst, although there was no obvious superiority for catalytic oxidation of $\mathrm{C}_{3} \mathrm{H}_{8}$. Particularly, the activity for catalytic NO oxidation into $\mathrm{NO}_{2}$ was significantly improved by using $\left[\mathrm{HOCH}_{2} \mathrm{CH}_{2} \mathrm{NH}_{3}\right]_{2} \mathrm{Pt}(\mathrm{OH})_{6}$. This indicates that $\left[\mathrm{HOCH}_{2} \mathrm{CH}_{2} \mathrm{NH}_{3}\right]_{2} \mathrm{Pt}(\mathrm{OH})_{6}$ is a better Pt-precursor compared to $\mathrm{Pt}\left(\mathrm{NH}_{3}\right)_{4}\left(\mathrm{NO}_{3}\right)_{2}$.

\section{5. $\mathrm{XRD}$ and $\mathrm{H}_{2}$ Temperature-Programmed Reduction $\left(\mathrm{H}_{2}-\mathrm{TPR}\right)$ Analysis}

Figure 5a showed the XRD patterns of the different catalyst samples. The diffraction peaks associated with ceria in the $\mathrm{CeO}_{2} / \mathrm{Al}_{2} \mathrm{O}_{3}$ and $\mathrm{CeO}_{2}-\mathrm{Pt} / \mathrm{Al}_{2} \mathrm{O}_{3}$ catalysts can be easily observed and exhibited well-crystallized fluorite-type phase [40]. The characteristic peaks appeared at $2 \theta=28.54^{\circ}$, $33.16^{\circ}, 47.58^{\circ}$ and $56.52^{\circ}$ are respectively assigned to the (111), (200), (220) and (311) surfaces of ceria nanocrystals. The domain size was calculated using the Scherrer Equation based on XRD line-width broadening data of the (111) surface. The average sizes of $\mathrm{CeO}_{2}$ nanoparticles in the $\mathrm{CeO}_{2} / \mathrm{Al}_{2} \mathrm{O}_{3}$ and $\mathrm{CeO}_{2}-\mathrm{Pt} / \mathrm{Al}_{2} \mathrm{O}_{3}$ catalysts were $7.0 \mathrm{~nm}$ and $4.1 \mathrm{~nm}$, respectively, indicating that the catalytic decomposition of cerium nitrate by $\mathrm{Pt}^{\delta+}$ species show a positive impact on promoting the dispersity of ceria. Co-existence of $\mathrm{Pt}^{4+}$ and $\mathrm{Pt}^{2+}$ species in $\mathrm{Pt} /$ alumina powder using $\left[\mathrm{HOCH}_{2} \mathrm{CH}_{2} \mathrm{NH}_{3}\right]_{2} \mathrm{Pt}(\mathrm{OH})_{6}$ as the Pt-precursor has been confirmed in our previous investigations [10]. The average size of $\mathrm{CeO}_{2}$ nanoparticles in the reference catalyst was bigger by comparison with the $\mathrm{CeO}_{2}-\mathrm{Pt} / \mathrm{Al}_{2} \mathrm{O}_{3}$ catalyst, reaching $5.4 \mathrm{~nm}$. The results illustrate that the presence of $\mathrm{Pt}^{4+}$ species has a better promotional effect on improving the dispersity of ceria than $\mathrm{Pt}^{2+}$ species. Besides, the ceria addition resulted in a significant decrease in the intensity of the peaks assigned to alumina supports, which can be ascribed to the Ce-promoted stability of alumina structures $[16,19]$. 

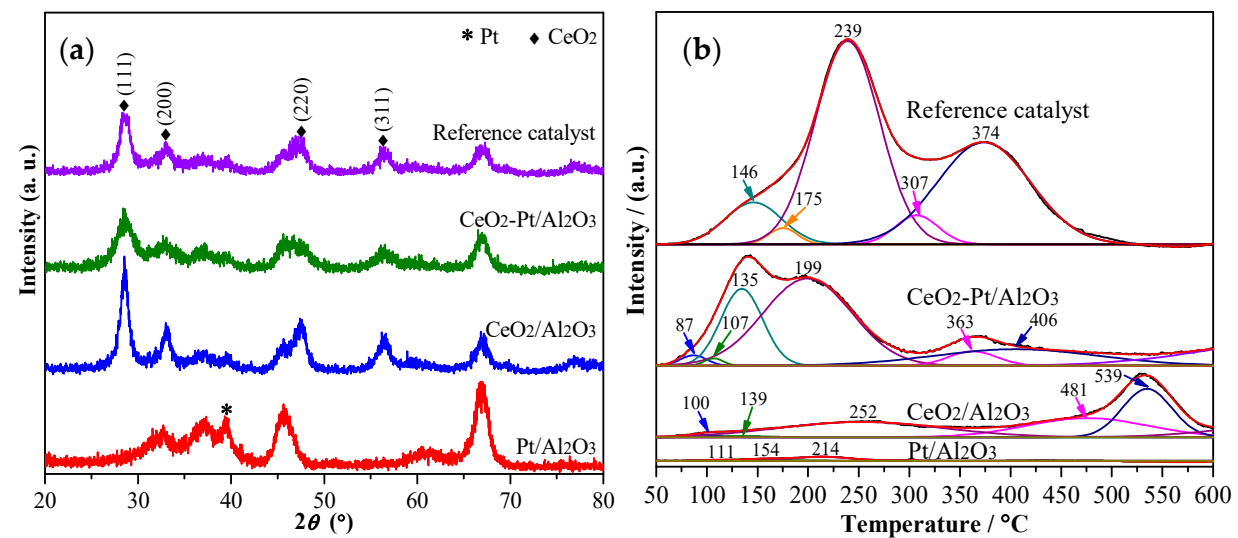

Figure 5. $\mathrm{XRD}$ patterns (a) and $\mathrm{H}_{2}$ temperature-programmed reduction $\left(\mathrm{H}_{2}-\mathrm{TPR}\right)$ profiles $(\mathbf{b})$ of the different catalyst samples.

The reducibility of the catalysts was also investigated by the $\mathrm{H}_{2}$-TPR measurement, and the results were shown in Figure $5 \mathrm{~b}$. In the case of the $\mathrm{Pt} / \mathrm{Al}_{2} \mathrm{O}_{3}$ catalyst, three $\mathrm{H}_{2}$ consumption peaks appeared at $111^{\circ} \mathrm{C}, 154^{\circ} \mathrm{C}$ and $214{ }^{\circ} \mathrm{C}$, respectively. The slight peaks centered at $111{ }^{\circ} \mathrm{C}$ and $154^{\circ} \mathrm{C}$ are closely related to the reduction of adsorbed oxygen on Pt nanocrystals and $\mathrm{O}^{2-}$ species bonded to surface platinum atoms, whereas, the peak centered at $214{ }^{\circ} \mathrm{C}$ should be assigned to the reduction of oxygen species that are adjacent to active $\mathrm{Pt}$ sites. As for the $\mathrm{CeO}_{2} / \mathrm{Al}_{2} \mathrm{O}_{3}$ catalyst, the reduction peaks at $100{ }^{\circ} \mathrm{C}$ and $139^{\circ} \mathrm{C}$ correspond to adsorbed oxygen species on ceria nanocrystals. The peaks at $252^{\circ} \mathrm{C}$ and higher temperatures are respectively associated with the reduction of activated surface oxygen species and shallow lattice oxygen in ceria by the following reaction (V) [10,40]. By contrast, the intensity of $\mathrm{H}_{2}$ consumption peaks below $250{ }^{\circ} \mathrm{C}$ strongly increased, and the peaks showed an obvious shift toward lower temperature, which indicates the significant increments of activated surface oxygen species and the increased reducibility of the $\mathrm{CeO}_{2}-\mathrm{Pt} / \mathrm{Al}_{2} \mathrm{O}_{3}$ catalyst. The $\mathrm{H}_{2}-\mathrm{TPR}$ profile of the reference catalyst exhibits the lower intensity of $\mathrm{H}_{2}$ consumption peaks below $200{ }^{\circ} \mathrm{C}$, and these peaks appeared at higher temperature compared with the $\mathrm{CeO}_{2}-\mathrm{Pt} / \mathrm{Al}_{2} \mathrm{O}_{3}$ catalyst, suggesting that the choice of Pt-precursors plays an important role in the reducibility of $\mathrm{Ce}$-containing catalysts and $\left[\mathrm{HOCH}_{2} \mathrm{CH}_{2} \mathrm{NH}_{3}\right]_{2} \mathrm{Pt}(\mathrm{OH})_{6}$ is an optimal precursor,

$$
2 \mathrm{CeO}_{2}+\mathrm{H}_{2} \rightarrow \mathrm{Ce}_{2} \mathrm{O}_{3}+\mathrm{H}_{2} \mathrm{O} \text {. }
$$

\section{Materials and Methods}

\subsection{Materials and Catalyst Preparation}

Bis(ethanolammonium)hexahydroxyplatinate(IV), $\left[\mathrm{HOCH}_{2} \mathrm{CH}_{2} \mathrm{NH}_{3}\right]_{2} \mathrm{Pt}(\mathrm{OH})_{6}$, was supplied by Sino-platinum metals Co., Ltd., Kunming, China. The nano-alumina was purchased from Aladdin, Shanghai, China. Cerium nitrate and aluminium nitrate were purchased from Xilong Chemical Co., Ltd., Guangzhou, China.

The $\mathrm{Pt} /$ alumina powder with the target $\mathrm{Pt}$ loading of $1.176 \%$ was prepared by incipient wetness impregnation of nano-alumina with an aqueous solution of $\left[\mathrm{HOCH}_{2} \mathrm{CH}_{2} \mathrm{NH}_{3}\right]_{2} \mathrm{Pt}(\mathrm{OH})_{6}$, followed by dry at $50{ }^{\circ} \mathrm{C}$ under vacuum condition overnight and calcination at $200{ }^{\circ} \mathrm{C}$ in $10 \% \mathrm{O}_{2} / \mathrm{N}_{2}$ stream for 30 min. The Pt/ $/ \mathrm{Al}_{2} \mathrm{O}_{3}$ catalyst was prepared by incipient wetness impregnation of the collected Pt/alumina powder. $17 \mathrm{~g}$ of the as-prepared Pt/alumina powder was added into $\mathrm{Al}\left(\mathrm{NO}_{3}\right)_{3}$ aqueous solution containing $29.42 \mathrm{mmol} \mathrm{Al} \mathrm{under} \mathrm{magnetic} \mathrm{stirring} \mathrm{at} \mathrm{room} \mathrm{temperature} \mathrm{for} 2 \mathrm{~h}$. The obtained slurries were dried at $50{ }^{\circ} \mathrm{C}$ under vacuum condition overnight and calcined at $550{ }^{\circ} \mathrm{C}$ in $10 \% \mathrm{O}_{2} / \mathrm{N}_{2}$ stream for $2 \mathrm{~h}$ with a heating rate of $10^{\circ} \mathrm{C} / \mathrm{min}$ in $\mathrm{N}_{2}$ stream to obtain the $\mathrm{Pt} / \mathrm{Al}_{2} \mathrm{O}_{3}$ sample. To synthesize the $\mathrm{CeO}_{2}-\mathrm{Pt} / \mathrm{Al}_{2} \mathrm{O}_{3}$ catalyst, $17 \mathrm{~g}$ of the prepared $\mathrm{Pt} /$ alumina powder was dispersed in an aqueous solution of $\mathrm{Ce}\left(\mathrm{NO}_{3}\right)_{3}$ containing $17.43 \mathrm{mmol} \mathrm{Ce}$, and then the obtained slurries were stirred, dried 
and calcined by the same procedures with the $\mathrm{Pt} / \mathrm{Al}_{2} \mathrm{O}_{3}$ sample. A reference catalyst was also prepared using tetraammineplatinum (II) nitrate as $\mathrm{Pt}$-precursor by the same procedures with the $\mathrm{CeO}_{2}-\mathrm{Pt} / \mathrm{Al}_{2} \mathrm{O}_{3}$ catalyst.

\subsection{Characterization}

The in situ diffuse reflectance infrared Fourier transformed spectroscopy (DRIFTS) spectra were collected on a Nicolet 6700 FT-IR spectrometer equipped with an MCT detector. As for in situ detection of the thermal decomposition process of Pt-precursor and Ce-precursor, $2 \mathrm{~g}$ of the pristine sample without calcination was firstly pretreated at $50{ }^{\circ} \mathrm{C}$ under vacuum condition for $10 \mathrm{~h}$. Then, background spectra were collected at every $50^{\circ} \mathrm{C}$ from $100{ }^{\circ} \mathrm{C}$ to $500^{\circ} \mathrm{C}$ in a flow of nitrogen $(50 \mathrm{~mL} / \mathrm{min})$ with a heating rate of $10^{\circ} \mathrm{C} / \mathrm{min}$. After cooling to room temperature, $100 \mathrm{mg}$ of as-pretreated catalyst sample was placed in the in situ cell, and each transient experiment was measured in $\mathrm{N}_{2}$ stream with a total flow rate of $50 \mathrm{~mL} / \mathrm{min}$. The same methods were taken with the background spectrum collection procedure to acquire DRIFTS spectra.

The thermal decomposition characteristics of Pt-precursor and Ce-precursor in $\mathrm{N}_{2}$ stream with a heating rate of $10^{\circ} \mathrm{C} / \mathrm{min}$ were examined by thermogravimetric (TG) analysis, using an STA 449 F3 thermoanalyzer. The pristine samples without calcination were firstly pretreated at $50{ }^{\circ} \mathrm{C}$ under vacuum condition for $10 \mathrm{~h} .100 \mathrm{mg}$ of as-pretreated sample was immediately placed in the pot of thermoanalyzer and heated at a rate of $10^{\circ} \mathrm{C} / \mathrm{min}$ from $50^{\circ} \mathrm{C}$ to $550^{\circ} \mathrm{C}$ in a flow of nitrogen $(50 \mathrm{~mL} / \mathrm{min})$.

X-ray diffraction (XRD) patterns were recorded on a Philips $X^{\prime}$ pert Pro diffractometer in the $2 \theta$ range of $5-90^{\circ}$ with an increment step of $0.02^{\circ}$, using a Ni filtered $\mathrm{Cu} \mathrm{K} \alpha$ radiation $(\lambda=0.15418 \mathrm{~nm})$ source. The X-ray tube was operated at $36 \mathrm{kV}$ and $30 \mathrm{~mA}$.

$\mathrm{H}_{2}$ temperature-programmed reduction $\left(\mathrm{H}_{2}\right.$-TPR) was carried out on CHEMBET 3000 automated chemisorption instrument equipped with a thermal conductivity detector (TCD). $100 \mathrm{mg}$ of sample was placed in a quartz $U$-tube reactor and pretreated in an airstream with a total flow rate of $50 \mathrm{~mL} / \mathrm{min}$ at $450{ }^{\circ} \mathrm{C}$ for $30 \mathrm{~min}$. After cooled to room temperature, $\mathrm{H}_{2}$-TPR experiments were performed in an $\mathrm{H}_{2}-\mathrm{Ar}\left(9.91 \%\right.$ of $\mathrm{H}_{2}$ by volume) stream with a total flow rate of $50 \mathrm{~mL} / \mathrm{min}$ from $50{ }^{\circ} \mathrm{C}$ to $620{ }^{\circ} \mathrm{C}$ at a heating rate of $10^{\circ} \mathrm{C} / \mathrm{min}$.

\subsection{Catalytic Performance Tests}

The catalytic oxidation activity of the catalysts was performed under atmospheric pressure in a continuous flow fixed-bed micro-reactor system. $500 \mathrm{mg}$ of the catalyst sample with an average diameter of 40-60 mesh was placed in a quartz tube with an inner diameter of $8 \mathrm{~mm}$ for activity measurements. The total flow rate was $500 \mathrm{~mL} / \mathrm{min}$ to make the gas hourly space velocity of (GHSV) value of $60,000 \mathrm{~mL} /(\mathrm{g} \cdot \mathrm{h})$. The outlet concentrations of reaction gases and gaseous products were analyzed online using a 2030DBG2EZKS13T MultiGas FT-IR Analyzer purchased from MKS Instruments, Inc. Prior to the activity measurement, each catalyst sample was pretreated at $500{ }^{\circ} \mathrm{C}$ in a flow of $\mathrm{O}_{2}-\mathrm{N}_{2}$ ( $10 \%$ of $\mathrm{O}_{2}$ by volume) mixture for $30 \mathrm{~min}$. The catalytic performance was tested in a continuous flow of the reaction mixture gas. The inlet composition of the reaction mixture gas was $500 \mathrm{ppm} \mathrm{CO}$, $200 \mathrm{ppm} \mathrm{NO}, 660 \mathrm{ppm} \mathrm{C}_{3} \mathrm{H}_{6}, 290 \mathrm{ppm} \mathrm{C}_{3} \mathrm{H}_{8}, 10$ vol. $\% \mathrm{O}_{2}, 8$ vol. $\% \mathrm{CO}_{2}, 5$ vol. $\% \mathrm{H}_{2} \mathrm{O}$ and $~ 77$ vol. $\% \mathrm{~N}_{2}$. NO conversion, $\alpha(\mathrm{NO}, \%)$, was calculated by the following Equation (1):

$$
\begin{gathered}
\alpha(\mathrm{NO}, \%)=\frac{\mathrm{C}_{\mathrm{NO}, \text { in }}-\mathrm{C}_{\mathrm{NO}, \text { out }}}{\mathrm{C}_{\mathrm{NO}, \text { in }}} \times 100 \%, \\
Y\left(\mathrm{NH}_{3}, \%\right)=\frac{\mathrm{C}_{\mathrm{NH}_{3}, \text { out }}}{\mathrm{C}_{\mathrm{NO}, \text { in }}} \times 100 \%, \\
Y\left(\mathrm{~N}_{2} \mathrm{O}, \%\right)=\frac{2 \times \mathrm{C}_{\mathrm{N}_{2} \mathrm{O}, \text { out }}}{\mathrm{C}_{\mathrm{NO}, \text { in }}} \times 100 \%,
\end{gathered}
$$




$$
Y\left(\mathrm{NO}_{2}, \%\right)=\frac{\mathrm{C}_{\mathrm{NO}_{2}, \text { out }}}{\mathrm{C}_{\mathrm{NO}, \text { in }}} \times 100 \%
$$

where, $C_{\mathrm{NO}, \text { in }}$ and $C_{\mathrm{NO}, \text { out }}$ represent the concentrations of the inlet and outlet $\mathrm{NO}$ gas, respectively. The $\mathrm{NH}_{3}, \mathrm{~N}_{2} \mathrm{O}$ and $\mathrm{NO}_{2}$ yields were calculated according to the Equations (2-4) on the basis of the outlet concentrations of $\mathrm{NH}_{3}, \mathrm{~N}_{2} \mathrm{O}$ and $\mathrm{NO}_{2}$ products, respectively. The values of $\mathrm{CO}, \mathrm{C}_{3} \mathrm{H}_{6}$ and $\mathrm{C}_{3} \mathrm{H}_{8}$ conversion rate were calculated by the same method associated with the calculation for $\mathrm{NO}$ conversion.

\section{Conclusions}

It was observed that Pt-catalyzed decomposition of cerium nitrate effectively increases the dispersity of ceria and significantly promotes the formation of activated surface oxygen species. The presence of $\mathrm{Pt}^{4+}$ species effectively improve the dispersity of ceria and readily increases the reducibility of Ce-containing catalysts. The undesirable $\mathrm{N}_{2} \mathrm{O}$ by-product was formed, due to the selective catalytic reduction of $\mathrm{NO}$ by $\mathrm{C}_{3} \mathrm{H}_{6}$ below $350{ }^{\circ} \mathrm{C}$, according to the results of in situ activity measurements. The $\mathrm{N}_{2} \mathrm{O}$ yield was increased by the addition of ceria, resulting from the increased reducibility of Ce-containing catalysts. The improved activity of $\mathrm{CeO}_{2}-\mathrm{Pt} / \mathrm{Al}_{2} \mathrm{O}_{3}$ catalyst for the catalytic $\mathrm{CO}, \mathrm{NO}, \mathrm{C}_{3} \mathrm{H}_{6}$ and $\mathrm{C}_{3} \mathrm{H}_{8}$ co-oxidation were attributed to its high reducibility and the high surface concentrations of activated oxygen species from the interactions between active $\mathrm{Pt}$ sites and ceria.

Author Contributions: Conceptualization and methodology, C.W. and Y.Z.; investigation and formal analysis, C.W. and J.D.; experiments and data curation, C.W., D.R. and Q.Q. and A.Z.; writing-original draft preparation and editing, C.W. and A.Z.; writing-review and project administration, L.C., H.C. and Y.Z.; funding acquisition, C.W., J.C. and Y.Z. All authors have read and agreed to the published version of the manuscript.

Funding: This research was supported by the National Natural Science Foundation of China $(21862010,51676017)$, the Provincial Applied Fundamental Research Program of Yunnan (2018FD140), the Major Science and Technology Programs of Yunnan (2019ZE001), and the Technology Talents and Platform Project of Yunnan (2018IC091).

Conflicts of Interest: The authors declare no conflict of interest.

\section{References}

1. Marcinkowski, M.D.; Darby, M.T.; Liu, J.; Wimble, J.M.; Lucci, F.R.; Lee, S.; Michaelides, A.; Flytzani-Stephanopoulos, M.; Stamatakis, M.; Sykes, E.C.H. Pt/Cu single-atom alloys as coke-resistant catalysts for efficient C-H activation. Nat. Chem. 2018, 10, 325-332. [CrossRef] [PubMed]

2. Sattler, J.J.H.B.; Ruiz-Martinez, J.; Santillan-Jimenez, E.; Weckhuysen, B.M. Catalytic dehydrogenation of light alkanes on metals and metal oxides. Chem. Rev. 2014, 114, 10613-10653. [CrossRef] [PubMed]

3. Herreros, J.M.; Gill, S.S.; Lefort, I.; Tsolakis, A.; Millington, P.; Mossb, E. Enhancing the low temperature oxidation performance over a $\mathrm{Pt}$ and a Pt-Pd diesel oxidation catalyst. Appl. Catal. B Environ. 2014, 147, 835-841. [CrossRef]

4. Gu, L.; Chen, X.; Zhou, Y.; Zhu, Q.; Huang, H.; Lu, H. Propene and CO oxidation on Pt/Ce-Zr-SO ${ }_{4}{ }^{2-}$ diesel oxidation catalysts: Effect of sulfate on activity and stability. Chin. J. Catal. 2017, 38, 607-616. [CrossRef]

5. Mathieu, O.; Lavy, J.; Jeudy, E. Investigation of hydrocarbons conversion vver a Pt-based automotive diesel oxidation catalyst: Application to exhaust port fuel injection. Top. Catal. 2009, 52, 1893-1897. [CrossRef]

6. AL-Harbi, M.; Hayes, R.; Votsmeier, M.; Epling, W.S. Competitive no, co and hydrocarbon oxidation reactions over a diesel oxidation catalyst. Can. J. Chem. Eng. 2012, 90, 1527-1538. [CrossRef]

7. Wang, C.; Tan, J.; Harle, G.; Gong, H.; Xia, W.; Zheng, T.; Yang, D.; Ge, Y.; Zhao, Y. Ammonia formation over $\mathrm{Pd} / \mathrm{Rh}$ three-way catalysts during lean-to-rich fluctuations: The effect of the catalyst aging, exhaust temperature, Lambda, and duration in rich conditions. Environ. Sci. Technol. 2019, 53, 12621-12628. [CrossRef]

8. He, J.; Wang, C.; Zheng, T.; Zhao, Y. Thermally induced deactivation and the corresponding strategies for improving durability in automotive three-way catalysts. Johns. Matthey Technol. Rev. 2016, 60, $196-203$. [CrossRef]

9. Jones, J.; Xiong, H.; DeLaRiva, A.T.; Peterson, E.J.; Pham, H.; Challa, S.R.; Qi, G.; Oh, S.; Wiebenga, M.H.; Hernández, X.I.P.; et al. Thermally stable single-atom platinum-on-ceria catalysts via atom trapping. Science 2016, 353, 150-154. [CrossRef] 
10. Wang, C.; Feng, F.; Du, J.; Zheng, T.; Pan, Z.; Zhao, Y. Activation of surface lattice oxygen in ceria supported $\mathrm{Pt} / \mathrm{Al}_{2} \mathrm{O}_{3}$ catalyst for low-temperature propane oxidation. ChemCatChem 2019, 11, 2054-2057. [CrossRef]

11. Nie, L.; Mei, D.; Xiong, H.; Peng, B.; Ren, Z.; Hernandez, X.I.P.; DeLaRiva, A.; Wang, M.; Engelhard, M.H.; Kovarik, L.; et al. Activation of surface lattice oxygen in single-atom $\mathrm{Pt} / \mathrm{CeO}_{2}$ for low-temperature $\mathrm{CO}$ oxidation. Science 2017, 358, 1419-1423. [CrossRef]

12. Bruix, A.; Lykhach, Y.; Matolínová, I.; Neitzel, A.; Skála, T.; Tsud, N.; Vorokhta, M.; Stetsovych, V.; Ševčíková, K.; Mysliveček, J.; et al. Maximum noble-metal efficiency in catalytic materials: Atomically dispersed surface platinum. Angew. Chem. Int. Ed. 2014, 53, 10525-10530. [CrossRef] [PubMed]

13. Liang, Y.; Ding, X.; Dai, J.; Zhao, M.; Zhong, L.; Wang, J.; Chen, Y. Active oxygen-promoted NO catalytic on monolithic Pt-based diesel oxidation catalyst modified with Ce. Catal. Today 2019, 327, 64-72. [CrossRef]

14. Ma, Z.; Wang, J.; Li, J.; Wang, N.; An, C.; Sun, L. Propane dehydrogenation over $\mathrm{Al}_{2} \mathrm{O}_{3}$ supported Pt nanoparticles: Effect of cerium addition. Fuel Process. Technol. 2014, 128, 283-288. [CrossRef]

15. Silva, F.A.; Martinez, D.S.; Ruiz, J.A.C.; Mattos, L.V.; Hori, C.E.; Noronha, F.B. The effect of the use of cerium-doped alumina on the performance of $\mathrm{Pt} / \mathrm{CeO}_{2} / \mathrm{Al}_{2} \mathrm{O}_{3}$ and $\mathrm{Pt} / \mathrm{CeZrO} \mathrm{rl}_{2} / \mathrm{Al}_{2} \mathrm{O}_{3}$ catalysts on the partial oxidation of methane. Appl. Catal. A Gen. 2008, 335, 145-152. [CrossRef]

16. Son, I.H.; Lane, A.M. Promotion of $\mathrm{Pt} / \gamma-\mathrm{Al}_{2} \mathrm{O}_{3}$ by Ce for preferential oxidation of $\mathrm{CO}$ in $\mathrm{H}_{2}$. Catal. Lett. 2001, 76, 151-154. [CrossRef]

17. Son, I.H. Study of Ce-Pt/ $\gamma-\mathrm{Al}_{2} \mathrm{O}_{3}$ for the selective oxidation of $\mathrm{CO}$ in $\mathrm{H}_{2}$ for application to PEFCs: Effect of gases. J. Power Source 2006, 159, 1266-1273. [CrossRef]

18. Wells, P.P.; Crabb, E.M.; King, C.R.; Fiddy, S.; Amieiro-Fonseca, A.; Thompsett, D.; Russell, A.E. Reduction properties of $\mathrm{Ce}$ in $\mathrm{CeOx} / \mathrm{Pt} / \mathrm{Al}_{2} \mathrm{O}_{3}$ catalysts. Catal. Struct. React. 2015, 1, 88-94. [CrossRef]

19. Onn, T.M.; Zhang, S.; Arroyo-Ramirez, L.; Xia, Y.; Wang, C.; Pan, X.; Graham, G.W.; Gorte, R.J. High-surface-area ceria prepared by $\mathrm{ALD}$ on $\mathrm{Al}_{2} \mathrm{O}_{3}$ support. Appl. Catal. B Environ. 2017, 201, 430-437. [CrossRef]

20. Damyanova, S.; Bueno, J.M.C. Effect of $\mathrm{CeO}_{2}$ loading on the surface and catalytic behaviors of $\mathrm{CeO}_{2}-\mathrm{Al}_{2} \mathrm{O}_{3}$-supported Pt catalysts. Appl. Catal. A Gen. 2003, 253, 135-150. [CrossRef]

21. Dawody, J.; Skoglundh, M.; Wall, S.; Fridell, E. Role of Pt-precursor on the performance of Pt/BaCO $3 / \mathrm{Al}_{2} \mathrm{O}_{3}$ NOx storage catalysts. Appl. J. Mol. Catal. A Chem. 2005, 225, 259-269. [CrossRef]

22. van den Tillaart, J.A.A.; Leyrer, J.; Eckhoff, S.; Lox, E.S. Effect of support oxide and noble metal precursor on the activity of automotive diesel catalysts. Appl. Catal. B Environ. 1996, 10, 53-68. [CrossRef]

23. Falco, M.G.; Canavese, S.A.; Fígoli, N.S. The calcination temperature after platinum addition and its effect on $\mathrm{Pt} / \mathrm{WOx}-\mathrm{ZrO}_{2}$ properties. Catal. Commun. 2001, 2, 207-211. [CrossRef]

24. Gao, Y.; Wu, X.; Nord, R.; Härelind, H.; Weng, D. Sulphation and ammonia regeneration of $\mathrm{Pt} / \mathrm{MnOx}-\mathrm{CeO}_{2} / \mathrm{Al}_{2} \mathrm{O}_{3}$ catalyst for NOx-assisted soot oxidation. Catal. Sci. Technol. 2018, 8, 1621-1631. [CrossRef]

25. Mueller, R.; Kammler, H.K.; Wegner, K.; Pratsinis, S.E. OH surface density of $\mathrm{SiO}_{2}$ and $\mathrm{TiO}_{2}$ by thermogravimetric analysis. Langmuir 2003, 19, 160-165. [CrossRef]

26. Dou, D.; Liu, D.J.; Williamson, W.B.; Kharas, K.C.; Robota, H.J. Structure and chemical properties of Pt nitrate and application in three-way automotive emission catalysts. Appl. Catal. B Environ. 2001, 30, 11-24. [CrossRef]

27. Aldiyarov, A.; Aryutkina, M.; Drobyshev, A.; Kurnosov, V. IR spectroscopy of ethanol in nitrogen cryomatrices with different concenteration ratios. Low Temp. Phys. 2011, 37, 524-531. [CrossRef]

28. Cabritaa, J.F.; Viana, A.S.; Mourato, A.; Montforts, F.P.; Abrantes, L.M. Self-assembled monolayers of metalloporphyrin phosphonates on electrochemically modified HOPG. Catal. Today 2012, 187, 70-76. [CrossRef]

29. Wallin, M.; Byberg, M.; Grönbeck, H.; Skoglundh, M.; Eriksson, M.; Spetz, A.L. Vibrational analysis of $\mathrm{H}_{2}$ and $\mathrm{NH}_{3}$ adsorption on $\mathrm{Pt} / \mathrm{SiO}_{2}$ and $\mathrm{Ir} / \mathrm{SiO}_{2}$ model sensors. In Proceedings of the IEEE Sensors 2007, Atlanta, GA, USA, 28-31 October 2007; pp. 1315-1317.

30. Carlsson, P.A.; Österlund, L.; Thormählen, P.; Palmqvist, A.; Fridell, E.; Jansson, J.; Skoglundh, M. A transient in situ FTIR and XANES study of $\mathrm{CO}$ oxidation over $\mathrm{Pt} / \mathrm{Al}_{2} \mathrm{O}_{3}$ catalysts. J. Catal. 2004, 226, 422-434. [CrossRef]

31. Solymosi, F.; Sárkány, J.; Schauer, A. Study of the formation of isocyanate surface complexes on $\mathrm{Pt} / \mathrm{AI}_{2} \mathrm{O}_{3}$ catalysts. J. Catal. 1977, 46, 297-307. [CrossRef] 
32. O'Brien, C.P.; Lee, I.C. A detailed spectroscopic analysis of the growth of oxy-carbon species on the surface of $\mathrm{Pt} / \mathrm{Al}_{2} \mathrm{O}_{3}$ during propane oxidation. J. Catal. 2017, 347, 1-8. [CrossRef]

33. Ermini, V.; Finocchio, E.; Sechi, S.; Busca, G. An FT-IR and flow reactor study of the conversion of propane on $\gamma-\mathrm{Al}_{2} \mathrm{O}_{3}$ in oxygen-containing atmosphere. Appl. Catal. A Gen. 2000, 190, 157-167. [CrossRef]

34. Azambre, B.; Zenboury, L.; Koch, A.; Weber, J.V. Adsorption and desorption of NOx on commercial ceria-zirconia $\left(\mathrm{Ce}_{\mathrm{x}} \mathrm{Zr}_{1-\mathrm{x}} \mathrm{O}_{2}\right)$ mixed oxides: A combined TGA, TPD-MS, and DRIFTS study. J. Phys. Chem. C 2009, 113, 13287-13299. [CrossRef]

35. Azambre, B.; Zenboury, L.; Delacroix, F.; Weber, J.V. Adsorption of $\mathrm{NO}$ and $\mathrm{NO}_{2}$ on ceria-zirconia of composition $\mathrm{Ce}_{0.69} \mathrm{Zr}_{0.31} \mathrm{O}_{2}$ : A DRIFTS study. Catal. Today 2008, 137, 278-282. [CrossRef]

36. Hadjiivanov, K.I. Identification of neutral and charged $\mathrm{N}_{\mathrm{x}} \mathrm{O}_{\mathrm{y}}$ surface species by IR spectroscopy. Catal. Rev. 2007, 42, 71-144. [CrossRef]

37. Wendlandt, W.W.; Bear, J.L. Thermal decomposition of the heavier rare-earth metal nitrate hydrates: Thermobalance and differential thermal analysis studies. J. Inorg. Nucl. Chem. 1960, 12, 276-280. [CrossRef]

38. Oh, H.; Luo, J.; Epling, W.S. NO oxidation inhibition by hydrocarbons over a diesel oxidation catalyst: Reaction between surface nitrates and hydrocarbons. Catal. Lett. 2011, 141, 1746-1751. [CrossRef]

39. Han, L.; Cai, S.; Gao, M.; Hasegawa, J.; Wang, P.; Zhang, J.; Shi, L.; Zhang, D. Selective catalytic reduction of $\mathrm{NOx}$ with $\mathrm{NH}_{3}$ by using novel catalysts: State of the art and future prospects. Chem. Rev. 2019, 119, 10916-10976. [CrossRef]

40. Wang, C.; Zheng, T.; Lu, J.; Wu, X.; Hochstadt, H.; Zhao, Y. Three-way catalytic reactions on Rh-based catalyst: Effect of Rh/ceria interfaces. Appl. Catal. A Gen. 2017, 544, 30-39. [CrossRef]

(C) 2020 by the authors. Licensee MDPI, Basel, Switzerland. This article is an open access article distributed under the terms and conditions of the Creative Commons Attribution (CC BY) license (http://creativecommons.org/licenses/by/4.0/). 